\title{
Dual roles of anterior cingulate cortex neurons in pain and pleasure in adult mice

Jing-Shan Lu ${ }^{1+}$, Qi-Yu Chen ${ }^{1+}$, Sibo Zhou' ${ }^{1}$, Kaoru Inokuchi ${ }^{2}$ and Min Zhuo ${ }^{1,3^{*}}$ (i)

\begin{abstract}
Human and animal studies indicate that some brain regions are activated during painful and pleasant situations, such as the anterior cingulate cortex (ACC). In the present study, we wanted to determine if some of the same neurons in the ACC may be activated by both pain and pleasure. We labeled neurons activated by two stimuli by using two immediate early genes (IEGs), Arc and Homerla, and detected the intranuclear transcription of the IEG mRNA in situ. We found that there are double-labeling neurons in the ACC after the mice received pain and sexual attraction stimulation. The double-labeling ACC neurons were higher in male mice exposed to female mice (attractive stimulus) than the group exposed to male mice (normal stimulus). The IEG, which indicates the sexual attraction, were also higher in the female exposing group, while the IEG indicating pain showed no significant variance between two groups. Our findings suggest that ACC neurons play important roles in the process of both pain and pleasure.
\end{abstract}

Keywords: IEG, ACC, Arc, Homer1a, Pain, Sexual attraction

\section{Main text}

Pain and pleasure are two major experiences in human and animals. We often pursue pleasure, while avoiding pain. The relationship between pain and pleasure can be further demonstrated by the analgesic effect of pleasure. Palatable food, pleasant odor, pleasurable music and sexual behavior were all found to reduce pain [1]. More interestingly, in certain conditions, pleasure can be gained by enduring pain, such as enjoying a spicy hotpot or receiving a massage. The central mechanism for pleasure is less investigated than the mechanism for pain, which has received more attention $[2,3]$. The ACC is well known to participate in pain sensation and nociceptive processing [4-7]. Less has been studied about the ACC's relationship to pleasure or happiness. It has been reported that the ACC is activated when a man views the picture of his lover [8]. Wu et al. has reported that ACC neurons of male mice could be activated after exposed to female mice [9]. However, it is unclear if pain or pleasure are processed through different population

\footnotetext{
* Correspondence: min.zhuo@utoronto.ca

† Jing-Shan Lu and Qi-Yu Chen contributed equally to this work

${ }^{1}$ Center for Neuron and Disease, Frontier Institute of Science and

Technology, Xi'an Jiaotong University, Xi'an 710049, China

${ }^{3}$ Departmentof Physiology, Faculty of Medicine, University of Toronto, 1

King's College Circle, Toronto, Ontario M5S 1A8, Canada

Full list of author information is available at the end of the article
}

of neurons, or if some ACC neurons may contribute to both pain and pleasure.

CatFISH serves as a functional imaging that allows investigators to distinguish neuronal populations activated by two distinct stimuli. The IEGs such as Arc, Homerla, zif268 and c-fos, were used in catFISH. Among them, the Arc/Homerla catfish method is a useful tool [10-12]. In this study, we used the Arc/Homer1a catFISH to distinguish two (pain and sexual attraction) stimuli and to identify ACC neurons that are activated by both stimuli.

We used an animal model of persistent inflammatory pain to induce pain [13]. We injected $5 \%$ formalin for $5 \mu \mathrm{l}$ into the left hind paws of adult male mice which were well habituated before the experiment (Fig. 1a). After the injection, mice were put into the open field, where there is a small cage in the center. Significant biting or licking behaviors were observed during the first $5 \mathrm{~min}$, after that, mice moved less in the open field and preferred to stay in the corners. (Fig. 1b). At 30 min later, a female or male mouse was introduced and put into the central cage (Fig. 1b). The behavior of the male mouse was monitored for another 5 min. We found that male mice spent most of their time surrounding the female mouse, and tried to enter the central cage (Fig. 1b left). By contrast, they showed less interest to the male mouse (Fig. 1b right). Mice were sacrificed immediately at $35 \mathrm{~min}$, and the brains were removed

(C) The Author(s). 2018 Open Access This article is distributed under the terms of the Creative Commons Attribution 4.0 International License (http://creativecommons.org/licenses/by/4.0/), which permits unrestricted use, distribution, and 
A

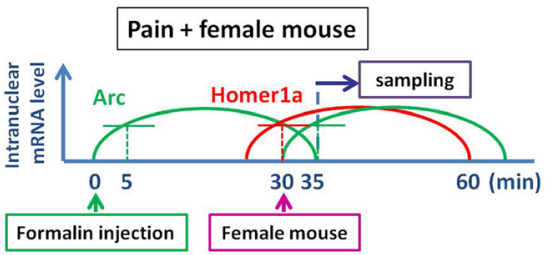

B

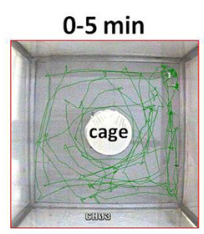

30-35 $\min$

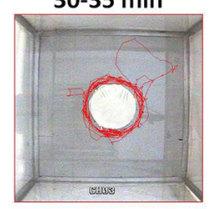

C

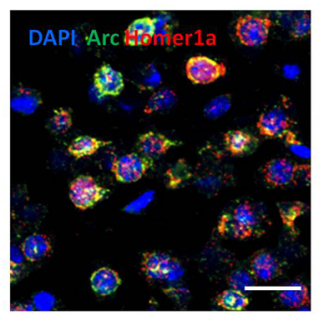

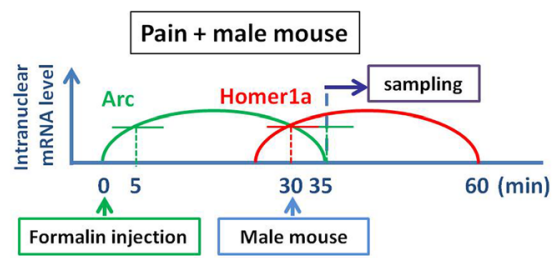
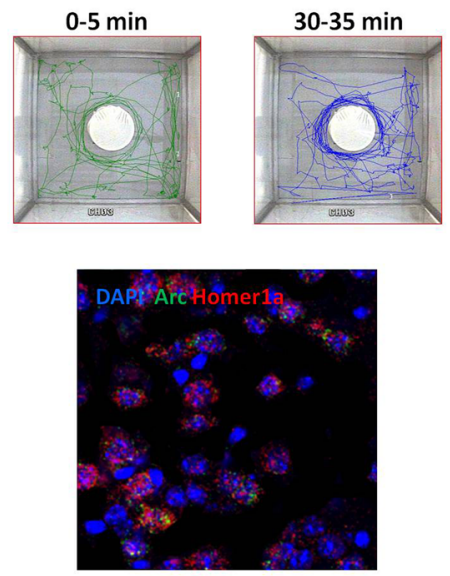

D
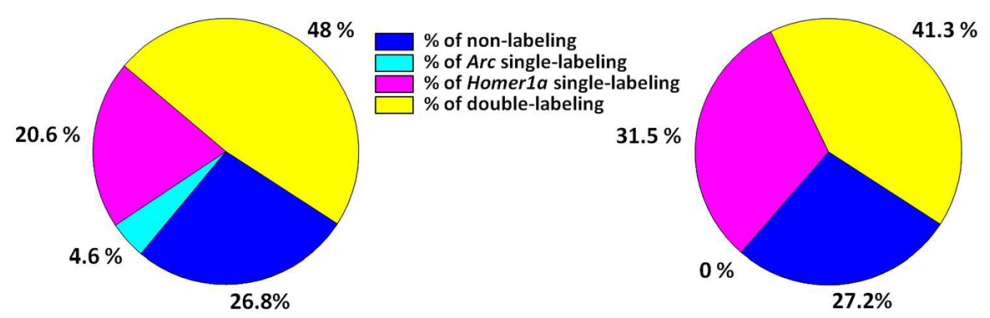

$\mathbf{E}$

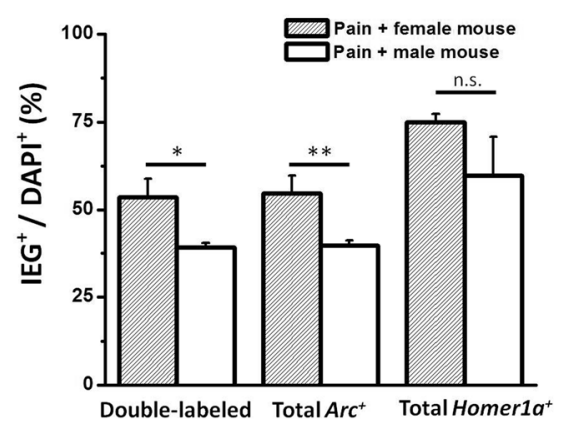

Fig. 1 Neurons encoding pain and sexual attraction information were co-labeled in the ACC of mice. a Stimulation patterns to induce the expression of the IEGs Arc and Homer1a. 5\% formalin for $5 \mu \mathrm{l}$ was injected into the left hind paw of the mice. Then the behaviors of the mice in the open field with a cage in the center were recorded. A female (Left) or male (Right) mouse was put into the central cage for 30 min, and the mice were sacrificed at $35 \mathrm{~min}$. b The tracks of the "pain + female mouse" group (left) and the "pain + male mouse" group (right) in 0 5 min and 30 35 min in the open field. c Neuronal staining profiles in the ACC of mice in the two groups. Arc (green) and Homerla (red) foci were detected in nuclei (DAPI-labeled, blue). Scale bar, $30 \mu \mathrm{m}$. d Sample pie figures of the percentages of double-labeling, Arc/Homerla single-labeling neurons in $\mathrm{DAPI}^{+}$neurons in ACC of the two groups. e Statistic result of the percentages of double-labeling, total Arc/Homerla-labeling neurons in DAPI ${ }^{+}$ neurons in ACC of the two groups. $n=5$ for "pain + female mouse" group; $n=3$ for "pain + male mouse" group. ${ }^{*} p<0.05,{ }^{*} p<0.01$, n.s. not significant

rapidly and quick-frozen. $20 \mu \mathrm{m}$-thick sections were prepared and mounted on slides. The catFISH process was carried out according to previous protocols $[10,11,14]$. In brief, riboprobes were transcripted from the Arc/Homerla cDNA clone and labeled by digoxigenin and fluorescein individually. After hybriding with Arc/Homerla mRNA on the slices in situ, anti-fluorescein/digoxigenin HRP and tyramide/cyanine-3 substrate of HRP were used to detect the Arc/Homerla probes. Nuclei were counterstained with DAPI. While double-labeled neurons 
were detected in both the "pain + female mouse" and the "pain + male mouse" groups, we found that the percentage of ACC double-labeled neurons was larger in the "pain + female mouse" group than that of "pain +male mouse" group (Fig. 1d, ${ }^{* * * * *} p<0.001$, chi-square test). The percentage of $\mathrm{Arc}^{+}$neurons, which indicates the sexual attraction activated neurons, was also higher in the "pain + female mouse" group than the "pain + male mouse" group (Fig. 1c, d, e, $n=5,3$ respectively; $* *<0.01$ ). The percentage of Homerla $a^{+}$in ACC neurons show no significant difference (Fig. 1c, d, e, $n=5,3$ respectively, $p>0.05$ ).

In conclusion, by applying the Arc/Homerla catFISH, we discovered that neurons encoding pain and sexual attraction information can be co-labeled in the same neurons of the ACC, which may indicate that pain and sexual attraction may be processed by some of the same neurons in the ACC. The molecular and synaptic mechanism still require further investigation.

\section{Abbreviations}

ACC: Anterior cingulate cortex; catFISH: Cellular compartment analysis of temporal activity by fluorescent in situ hybridization; DAPI: 4,6-diamidino-2phenylindole; IEG: Immediate early gene

\section{Acknowledgements}

The authors would like to thank Masanori Nomoto for the guidance of catFISH work. We also thank Fang Yue and Yong-Ming Liu for their contributions to the study.

\section{Funding}

This work was partially supported by grants from the CIHR project grant (PJT-148648) awarded to MZ.

\section{Availability of data and materials}

Data sharing not applicable to this article as no datasets were generated or analyzed during the current study.

\section{Authors' contributions}

JSL and QYC designed and performed the experiments then analyzed the data. KI provided plasmids containing Arc/Homer 1 a cDNA. SBZ also participated in the experiments. JSL, QYC and MZ drafted the manuscript and finished the final version of the manuscript. All authors read and approved the final manuscript.

\section{Ethics approval and consent to participate}

Not applicable

\section{Consent for publication}

Not applicable

\section{Competing interests}

The authors declare that they have no competing interests.

\section{Publisher's Note}

Springer Nature remains neutral with regard to jurisdictional claims in published maps and institutional affiliations.

\section{Author details}

${ }^{1}$ Center for Neuron and Disease, Frontier Institute of Science and Technology, Xi'an Jiaotong University, Xi'an 710049, China. ${ }^{2}$ Department of Biochemistry, Graduate School of Medicine and Pharmaceutical Sciences, University of Toyama, 2630 Sugitani, Toyama 930-0194, Japan. ${ }^{3}$ Departmentof Physiology, Faculty of Medicine, University of Toronto, 1 King's College Circle, Toronto, Ontario M5S 1A8, Canada.
Received: 25 October 2018 Accepted: 27 November 2018

Published online: 04 December 2018

\section{References}

1. Leknes S, Tracey I. A common neurobiology for pain and pleasure. Nat Rev Neurosci. 2008:9:314-20.

2. Bushnell MC, Ceko M, Low LA. Cognitive and emotional control of pain and its disruption in chronic pain. Nat Rev Neurosci. 2013;14:502-11.

3. Kuner R, Flor H. Structural plasticity and reorganisation in chronic pain. Nat Rev Neurosci. 2017;18:113.

4. Bliss TV, Collingridge GL, Kaang BK, Zhuo M. Synaptic plasticity in the anterior cingulate cortex in acute and chronic pain. Nat Rev Neurosci. 2016; 17:485-96.

5. Zhuo M. Cortical excitation and chronic pain. Trends Neurosci. 2008;31:199-207.

6. Vogt BA. Pain and emotion interactions in subregions of the cingulate gyrus. Nat Rev Neurosci. 2005;6:533-44

7. Zhuo M. Long-term potentiation in the anterior cingulate cortex and chronic pain. Philos Trans R Soc Lond Ser B Biol Sci. 2014;369:20130146.

8. Arnow BA, Desmond JE, Banner LL, Glover GH, Solomon A, Polan ML, Lue TF, Atlas SW. Brain activation and sexual arousal in healthy, heterosexual males. Brain. 2002;125:1014-23.

9. Wu LJ, Kim SS, Li X, Zhang F, Zhuo M. Sexual attraction enhances glutamate transmission in mammalian anterior cingulate cortex. Mol Brain. 2009;2:9.

10. Vazdarjanova A, McNaughton BL, Barnes CA, Worley PF, Guzowski JF. Experience-dependent coincident expression of the effector immediateearly genes arc and Homer 1a in hippocampal and neocortical neuronal networks. J Neurosci. 2002;22:10067-71.

11. Guzowski JF, McNaughton BL, Barnes CA, Worley PF. Environment-specific expression of the immediate-early gene arc in hippocampal neuronal ensembles. Nat Neurosci. 1999;2:1120-4.

12. Femino AM, Fay FS, Fogarty $K$, Singer RH. Visualization of single RNA transcripts in situ. Science. 1998;280:585-90.

13. Wu ப, Steenland HW, Kim SS, Isiegas C, Abel T, Kaang BK, Zhuo M. Enhancement of presynaptic glutamate release and persistent inflammatory pain by increasing neuronal CAMP in the anterior cingulate cortex. Mol Pain. 2008:4:40.

14. Nomoto M, Ohkawa N, Nishizono H, Yokose J, Suzuki A, Matsuo M, Tsujimura S, Takahashi Y, Nagase M, Watabe AM, et al. Cellular tagging as a neural network mechanism for behavioural tagging. Nat Commun. 2016;7:12319.

\section{Ready to submit your research? Choose BMC and benefit from:}

- fast, convenient online submission

- thorough peer review by experienced researchers in your field

- rapid publication on acceptance

- support for research data, including large and complex data types

- gold Open Access which fosters wider collaboration and increased citations

- maximum visibility for your research: over $100 \mathrm{M}$ website views per year

At $\mathrm{BMC}$, research is always in progress.

Learn more biomedcentral.com/submissions 